This item was submitted to Loughborough's Research Repository by the author.

Items in Figshare are protected by copyright, with all rights reserved, unless otherwise indicated.

\title{
"I feel English as fuck": translocality and the performance of alternative identities through rap
}

PLEASE CITE THE PUBLISHED VERSION

https://doi.org/10.1080/01419870.2019.1623411

\section{PUBLISHER}

(C) Taylor \& Francis (Routledge)

\section{VERSION}

AM (Accepted Manuscript)

\section{PUBLISHER STATEMENT}

This is an Accepted Manuscript of an article published by Taylor \& Francis in Ethnic and Racial Studies on 15 Jul 2019, available online: https://doi.org/10.1080/01419870.2019.1623411

\section{LICENCE}

CC BY-NC-ND 4.0

\section{REPOSITORY RECORD}

Bramwell, Richard, and James Butterworth. 2019. "'I Feel English as Fuck": Translocality and the Performance of Alternative Identities Through Rap". Loughborough University. https://hdl.handle.net/2134/37500. 


\title{
'I feel English as fuck': translocality and the performance of alternative identities through rap
}

Richard Bramwell ${ }^{1}$ and James Butterworth

School of Social Sciences, Loughborough University, Loughborough, UK

\section{Article History}

Received 26 April 2018; Accepted 2 April 2019

\begin{abstract}
This article deploys the concept of translocality, in order to move beyond the transnational framework that underpins global hip hop studies. Over the last 40 years rap music has become a vibrant and distinctive part of mainstream British life. Through rap young people construct identities that draw upon their local experiences while also connecting them with young people from other localities. These translocal identities affirm a multi-ethnic, urban experience of England in mainstream popular culture. Based on a year of ethnographic research in London and Bristol, we argue that a distinctive rap culture is produced through the performance, production, circulation, and reproduction of rap in and between English cities.
\end{abstract}

Keywords translocality, grime, rap, performance, identity, global hip hop

In recent decades there has been a proliferation of scholarly work examining the circulation of rap music around the world. The publication in 2001 of Global Noise: Rap and Hip Hop Outside the USA, edited by Tony Mitchell, can be taken as a key marker in the development of the field of hip hop studies. This collection of essays highlighted the burgeoning literature concerned with documenting and analysing 'global' hip hop. Whereas, during the 1990s, the emergent field of hip hop studies was characterised by a focus on the US (Perkins 1996; Rose 1994) the turn of the millennium saw an increasing interest in the trans- and inter-national communicative networks through which this cultural form circulated. The bulk of what has come to be known as global hip hop studies has centred on hip hop in specific local or national contexts outside of the US and, in many cases, charted the

\footnotetext{
${ }^{1}$ Contact Richard Bramwell r.bramwell@lboro.ac.uk
} 
relationship between hip hop in the US and hip hop in specific 'elsewheres' (Condry, I. 2006; Nitzsche, S. and Grunzweig, W. 2013). Global Noise and many subsequent publications have also problematized the idea that hip hop is an inherently AfricanAmerican cultural form, arguing for its value and meaning among a range of marginalised social groups worldwide.

In this context, it is striking how relatively little research has been conducted on rap cultures in the UK. Other than Paul Gilroy's discussions of the role of hip hop in black British $(1987 ; 2004)$ and black Atlantic (1993) cultures, Hesmondhalgh and Melville's (2001) contribution to Global Noise, and Bennett's (1999a) article on rap and white-working-class identities in Newcastle, rap in the UK has been significantly under studied until very recently. The last few years, however, have seen scholars giving British hip hop and grime long overdue attention (Bramwell 2015, 2017;

Dedman 2011; Turner 2017; White 2016, 2017). While common narratives pinpoint the USA as the birthplace of hip hop and then track its movement outwards (Mitchell 2001), the history of rap in the UK tells a different story. Although rap cultures in Britain have been influenced by US hip hop in a variety of ways, they have parallel, as opposed to subsequent, histories, developing over several decades with their own debts to a range of Caribbean-derived oral poetic and dance music forms (Back 1988; Johnson 1976; Hesmondhalgh and Melville 2001). Rap in Britain has significantly changed over the last 40 years and, since the birth of grime in the early 200os, rap by English artists has taken a prominent position in the mainstream of British life, while still operating as an important subcultural form. Whether explicitly (Nitzsche and Grünzweig 2013) or implicitly (Bennett 1999a, 1999b), global hip hop studies has privileged a transnational paradigm with the USA as the central node in the network. However, we argue that this paradigm is unsuited to the analysis of rap in the United Kingdom. Instead, we develop a translocal ethnographic approach through which to 
examine the grassroots production of rap culture in two English cities, focussing on connections and contingencies within, rather than across, national boundaries.

\section{Translocality, placed based identities, and rap cultures}

Our analysis of the performance and circulation of rap culture draws on debates around translocality. This concept has been used for some time to examine flows of people and culture. Greiner and Sakdapolrak (2013) identify that scholars from a variety of traditions, including geography, cultural studies and anthropology, have used the term to 'describe socio-spatial dynamics and processes of simultaneity and identity formation that transcend boundaries - including, but also extending beyond, those of nation states'. Brickell and Datta (2011) highlight that the concept developed out of debates on transnationalism: 'the history of translocality itself which has emerged from a concern over the disembedded understanding of transnational networks. Research on translocality primarily refers to how social relationships across locales shape transnational migrant networks, economic exchanges and diasporic space.' Although Brickell and Datta's emphasis on migration leads them to focus on transnational movement and networks, Smith (2011) observes 'Not all translocal connections are necessarily transnational'. Significantly, Appadurai (1996) identifies how, through the use cultural products circulated by communicative technologies, local subjectivity is produced and nurtured through a 'palimpsest of highly local and highly translocal considerations.' We deploy translocality to examine how place based identities are performed in particular locations, how these performances are circulated, and how they are informed by performances in other localities. In this manner we draw on Appadurai's mobilization of translocality to draw attention to the inadequacy of dominant discourses of national belonging to young people's lived experiences and to analyse how these youths produce alternative identifications within the UK. 
While a number of scholars have employed translocality to examine hip hop or rap culture, these studies tend to highlight the connections between one particular city or field site and a globalised hip hop culture. This can be seen in Darling-Wolf's analysis of rap in France, which identifies how French rappers are able to adopt a position of resistance, in opposition to American cultural dominance. Although she states that French rap embodies a banlieue culture, which is 'steeped in experiences of immigration, diaspora, (post)colonialism, and racial struggle', Darling-Wolf (2008) acknowledges that her study neglects to examine the local-local connections within France as well as with other francophone environments. Elafros (2013) uses the term 'translocal authentication' in her study of Greek hip hop, to examine how some hip hop practitioners have 'sought to legitimate rap as a type of transnational popular culture within the transnational field of cultural production.' Elafros (2013) contrasts these practitioners with those who engage in 'local authentication' by adopting Greek musical elements in cultural production. This focus on the adaptation of transnational hip hop culture to a 'local' context, through the incorporation of elements of national culture, is consistent with the majority of scholarship in the field of global hip hop studies.

Eric Ma's study of Hong Kong bandrooms adopts a translocal focus through which to examine how one particular bandroom, the a.room, is connected to other spaces in the city. However, despite his aim of examining 'the translocal spatiality of local/local dynamics', Ma's (2002) discussion of hip hop culture (through the connections that band members have with American hip hop practitioners and their appearances on Japanese radio stations) returns to a transnational frame. As with Elafros, for Ma a globalised hip hop culture is localised within this new context. By contrast Birgit Englert's (2018) study of popular music in Marseilles draws on the concepts transnationality and translocality, and emphasises the need to use these related concepts carefully, ensuring 'that the two do not become conflated.' Englert (2018) uses translocality to examine how Sopranos, a French- 
Comoran rap artist, prioritises his Marseillais identity over his French identity. Although Englert discusses Sopranos' musical representations of a 'cosmopolitan’ Marseilles, through the lens of translocality, her focus on one particular artist does not address the mechanisms through which a translocal French rap culture is produced in everyday social life. In this study, we highlight how a distinctive, 'UK' rap culture is produced through local performance and translocal dissemination of rap songs. By focusing on grassroots rap culture, we explore how ordinary young people construct translocal subjectivities through the production and use of rap lyrics and music videos.

This article is grounded in a translocal ethnographic approach, involving sustained fieldwork in the St Paul's area of Bristol (South West England) and the areas of Newham and Brixton in London. St Paul's is an inner-city area of Bristol, which from the midtwentieth century became a home for migrants from Jamaica and other Caribbean islands. Today it is one of the most ethnically diverse parts of the city. The majority of our research in St Paul's centered on Docklands Youth Centre, where dozens of young people from the neighborhood participated in live rap performance and studio production, the vast majority of whom were black. Brixton in South London and Newham in East London are also ethnically diverse inner-city areas and Brixton, like St Paul's in Bristol, became home to many of the Carribeans who emigrated to Britain following the end of the Second World War. As part of our fieldwork in Newham we visited several youth centres where rap was part of young people's activities to varying degrees. In Brixton, our research took place in a community centre and a youth arts charity, Raw Material, with extensive support and resources for music performance and studio production.

\section{Rap in the United Kingdom}

As this paper will focus on rap performances in England it is necessary to explain our use of the terms rap, hip hop and grime, particularly as rap and hip hop are often conflated in public discourse. We use the term rap to refer to the practice of lyrical performance, by an 
MC or rapper, often over an instrumental background (Bennett 1999a; Kajikawa 2015). Our interest in hip hop and grime arises as rap is an important component in both genres of music and the subcultures associated with them. Whereas grime is closely associated with the United Kingdom and specifically London, from where it is regarded to have emerged (Dedman 2011; White 2016; Hancox 2018), hip hop is historically linked to the South Bronx (Rose 1994; Chang 2005), and has since become one of the biggest selling global popular music genres. Both hip hop and grime culture are indebted to Jamaican sound-system culture and reggae 'toasting' (Back 1988; Chang 2005; Bramwell 2015). By focusing our analysis around rap, we wish to cut across musical genres and to acknowledge the presence of this cultural practice in Britain prior to the global spread of hip hop in the 1980 s and 1990 s.

Rap in the UK is indebted to the development of black Atlantic culture (Heathcott 2003) from the mid-twentieth century, which involved transcultural flows between cities such as Kingston in Jamaica, and London and Manchester in the UK. The first Jamaican style sound systems were built in the UK, not long after the arrival of the Jamaican sound system operators in the 1950s (Bradley 2013). With leading figures such as Lloyd Coxsone and Denise Bovell, London's sound systems led to the development of the, distinctively British, Lover's Rock reggae genre, and then, later, jungle music and grime (Bradley 2013). Les Back's (1988) study of sound systems in south east London identifies the similarities between the organisation of this black British culture and US hip hop. Back examines how sound systems and 'Microphone Chanters' in London differentiated themselves from their Jamaican counterparts through their use of 'British Youth Caribbean Creole' and the depiction of everyday life in the UK. Both Back (1988) and Melville and Hesmondhalgh (2001) identify how pre-existing British Caribbean cultural practices facilitated the adoption and popularisation of hip hop music in Britain. 
UK hip hop emerged as a vibrant and distinctive scene during the late 1980 os and early 1990s, with MCs such as Rebel MC, Black Twang, and the London Posse, drawing overtly on US hip hop styles while also incorporating influences from England and the Caribbean. Alongside the emergence of this scene, the development of jungle (Bradley 2013) and the crossover success of 'Incredible' by M-Beat with General Levy in 1994 (Noys 1995), reveal a continuing identification with the Caribbean within black British culture. At the beginning of the new millennium a significant shift occurred in British rap culture, with the emergence of grime. A generation of MCs that had grown up immersed in reggae culture (including Wiley and other members of the Pay As You Go Cartel) emerged through the structures of the UK Garage scene, producing a distinctively new sound (Bramwell 2015). 'Reggae suffused the general atmosphere that the grime generation grew up in, tracing direct ancestral links from Britain's pre-acid house reggae culture, some of it imported from the Caribbean, some of it created by black Britons' (Hancox 2018). In 2003 Dizzee Rascal was awarded the Mercury Music Prize for his album Boy In Da Corner. Since then, grime's rise - and the string of top ten singles that accompanied it - has made an important contribution to the mainstreaming of black culture in the United Kingdom.

More recently drill, which developed out of the trap music genre in Chicago (Thapar 2017), has risen to prominence in Britain. In contrast to grime's association with east London, 'UK drill' is popularly associated with sites in south London, including Brixton and Tulse Hill, although it has spread much more widely. The lyrics of this rap genre are marked by territorial claims, affirmations of gang affiliation, and frequent acts of violence. The popularity of this genre and associations made between the music and rising knife crime in London, have led to increasing surveillance of music videos by the police and youth offending teams (White 2017). While we use the term rap to refer to the verbal practice of rapping, which cuts across musical genres, the young people we spoke with had 
a keen understanding of generic distinctions and made conscious decisions about the genres they would employ in their creative practice.

Over the course of this paper we explore how, through the performance of rap lyrics and the circulation of rap culture, English youths represent their experiences and identifications, sharing these with other young people in cities across the country. We highlight the role that digital communications play in the processes of production, dissemination and consumption. Young people use these communicative technologies to give shape and meaning to an alternative mode of life in England. In contrast to pervasive nostalgia around Englishness as rural idyll, this alternative mode of life is very much set in the present, it is future oriented, and it is urban.

\section{Place and race in rap performance}

In his critique of cultural studies, Arjun Appadurai (1996) raises the question of the type of ethnographic practice appropriate to the examination of translocalities. We draw on multisited ethnographies of urban youth culture (Bramwell 2015; James 2015). However, we have broadened our focus beyond the limits of the city or the borough, in order to work towards the development of a translocal ethnographic practice. This study of the performance of identity through rap was conducted as part of a larger study of rap culture within a variety of state-funded institutions in England. Like previous studies of rap culture in the UK (Bramwell 2015; White 2016; Turner 2017) we employed semi-structured interviews and participant observation and, additionally, used a video recorder in order to capture rap in performance as an embodied, ephemeral and social practice. We conducted more than twenty interviews with young adults and youth workers in youth centres, a community centre and an arts charity, spanning sites in London and Bristol. We also engaged in numerous informal conversations with youths under the age of 16 . Interviews lasted on average one hour and twenty minutes, with longer interviews (of up to three hours) conducted over two or three sessions. All interviews were recorded on a dictaphone, 
with the consent of those participating. Interviewees were given the option to not remain anonymous so that they could be credited for their ideas on rap culture (Elafros 2013). Our routes into the various organisational settings in which we worked were through managers, who introduced us to staff and young people. Interviews were conducted either in these institutional settings or nearby in the local area. We observed hundreds of rap performances - from the staged to the spontaneous - by research participants in the arts charity, community centre and youth centres, as well as outside them, over the course of one year of fieldwork.

Spirits are high in the studio on a warm Friday evening in May. It's Billy's birthday and a group of five MCs are gathered together with Latoya, a producer, in one of the recording studios at Raw Material, a youth arts charity in Stockwell, south London. Billy, holding a microphone in his hand, stands opposite Armani, as the others look on. As part of a freestyle battle, he gestures towards and points at his opponent as he raps his lyrics into the mic: 'Call me the white man, call me a Richardson. Where the fuck I come from, I come from Brixton!' As he continues, Billy undermines Armani first by attacking his opponent's lyrics, then by claiming sexual relations with the rapper's girlfriend, and finally by questioning Armani's integrity: 'What are we saying, cause those bars ain't really righteous. What are we saying, cause I saw you going to pick up the glock, cuz. ... What are we saying done know I just fucked your bitch. Anyway, done know I heard that you're a snitch'. At one point Billy's friend and collaborator, Ishaaq, places his arm around him and chimes in with the invective Billy directs at his antagonist. In the same moment Armani raises his fist to be touched by Billy's. The audience respond to the performance with laughter, before Ishaaq takes the microphone and repeats the phrase 'little nigger, run and hide' while gesturing with his hand towards Armani. The event is imbued with humour and Armani laughs at some of the most cutting remarks. 
Billy's performance deploys a variety of references through which this young, white, working class man constructs his persona, Billski. In particular the defensive statements 'call me the white man, call me a Richardson', which highlight Billy's racial identity and then associate it with infamous members of south London's organised crime world, are followed by a declaration of the rapper's claim to a location strongly associated with black British cultural production and political activism ('where the fuck I come from, I come from Brixton'). In this manner, Billski prioritises place over race in the construction of his identity. Brixton's ethnic and cultural associations play an important role in this conjuring of identity. Billy (who lives nearby in Stockwell) solicits identification from members of the audience, who acknowledge his claim to 'come from Brixton' and appreciate the cultural significance of this topos.

Murray Forman (2000) argues that in rap music 'space and race figure prominently as organising concepts implicated in the delineation of a vast range of fictional or actually existing social practices'. In this event, we also see how these concepts are invoked through performance and used to solicit identification and produce a collective identity. Gilroy's emphasis on the practical activity through which black identity is produced is useful in considering how race, space and place are used to conjure Billski's persona in this performance: 'Though this identity is often felt to be natural and spontaneous, it remains the outcome of practical activity: language, gesture, bodily signification, desires' (Gilroy 1991: 127). The performance is structured and unfolds through oral exchange, physical gestures and bodily contact between Billy and Armani as well as between the two central performers and the others present. Significantly, with the exception of Billy, all the participants in this event are either black British African or black British Caribbean. Billski is brought into social being through a combination of linguistic skill, references to race and place, bodily gestures, and the audience's affirmation of Billy's belonging to a multi-ethnic community. 
It is also important to note that, not only do race and space figure within the performance, but the performance takes place in an institutional setting: a youth arts charity. This institution, Raw Material, facilitates participation in rap culture, in a similar manner to the 'alternative spaces of culture' discussed by Hoyler and Mager (2005) in relation to German youth and community centres. Prior to rapping his response to Billy, Armani repeats the phrase 'that's alright', over the audience's laughter, before a brief exchange between the pair:

Armani: 'that's alright ... Billski, because we look up to you anyway, yeah. Champion, you get me? Once a King, always a King, you see me? I'm not really much of a freestyler anyway. Let's see what we got here.'

Billy: 'You asked for it'

Armani: 'Yeah I know, I did! 'cause that's the only way you get better.'

The exchange highlights how this performance constitutes part of an informal learning process. Both Billy and Armani are engaged in the demonstration and development of their craft. Furthermore, the members of the group assembled in this space are all participating in the construction of identity through their practical activity. Significantly the Billski persona is performed through an identification with a place long associated with black popular culture, as well as the simultaneous invocation and dismissal of racial difference. This identity is affirmed through the physical and oral participation of the audience in this performance. While humour plays a significant role in affirming this identity, it is important to note that it is grounded through a rhetorical invocation of place, and Brixton's distinctive ethnoscape.

\section{Translocality and the 'UK' rap scene}

The importance of local identity to rap culture has been evident in our fieldwork in both London and Bristol. This emerges through written lyrics, bodily gestures and speech acts 
as well as through social relations and the use of cultural products. However, identification with the local often operates alongside a corresponding emphasis on the translocal, as rappers reference, listen to, connect themselves with, and distinguish themselves from, the locals of other English cities. While geographers have long used the concept of translocality to analyse cultural and migratory flows (Brickell and Datta 2011), it has most often been deployed in the examination of connections across or outside of national boundaries (Greiner and Sakdapolrak 2013). As a result of our focus on rappers' representations of contemporary urban dwelling, we wish to highlight that alongside the construction of identifications beyond the limits of the national (Elafros 2013; Ma 2002), translocality might be fruitfully employed in the examination of connections within the nation (Englert 2018) and deployed in understanding how the nation itself is (re)imagined.

In addition to constructing their identities through lyrical references to their locality, aspiring rappers' use of rap music and videos draws attention to the translocal networks through which rap culture is formed. On several occasions we encountered boys at the Docklands Youth Centre, in St Paul's, Bristol, watching music videos made by other young people in Bristol and beyond, which had been uploaded to YouTube. The Docklands boys would collectively view and discuss these videos. A large number of these were shot in and around Brixton, in London. In particular, the 67 crew, who hailed from Brixton, were well known amongst the boys at Docklands through these videos. We observed one of the Docklands boys making his own recording in the studio, drawing on lyrics from a 67 video. While London was clearly an important city in the imagination of aspiring artists at the youth centre, specific parts of the capital had a special resonance for these youths and young adults in the St Paul's area of Bristol. All but a couple of the dozens of boys we observed in the studio at Docklands over six months were black, and Brixton - as a hub of black British cultural production - was a key node in the public to which they were oriented. 
We have touched upon the significance of Brixton in our discussion of the construction of Billy's 'Billski' persona, above. However, what we want to emphasise here is how rap culture is constructed through the performance of rap lyrics and the circulation of rap music videos via social media. Through the performance, dissemination, consumption and reuse of rap lyrics, young people develop translocal subjectivities. Significantly the vast majority of YouTube videos viewed by the boys at Docklands featured boys from either Bristol or other English cities (i.e. not from the rest of the rest of the UK, nor from the US). Here, translocality can be used to understand how a distinctive, grassroots, rap culture is produced through a network of exchange, that privileges neighbourhoods in English towns and cities with large working-class and ethnic minority populations.

The interplay between the local and the translocal is apparent in the self description of Stripzz, a 17 year-old rapper from Bristol. During our fieldwork, Stripzz regularly attended Docklands youth centre. He had recorded several songs and performed as part of the collective Oosowavey, which had formed at the youth centre. This aspiring artist's explanation of the importance of representing his city, deploys references to the UK, Bristol and other English cities:

I'm a UK guy, wanna represent UK, do you know what I mean? ... this is where I'm from. And it's not even specifically UK, it's mainly Bristol. Bristol's an underated city, the music scene here is amazing. ... London, it's the capital and everyone is straight to London but I believe Bristol, we're just as good as London.

Like his contemporaries at Docklands youth centre, Stripzz regularly mentions Bristol in his lyrics and makes shout outs to other Bristol rappers. Just as the Bristol scene is discursively constituted through the production and circulation of these rap songs, an English rap culture emerges through a network of urban centres that operate as symbolic as well as physical locations of cultural production. Stripzz spoke of taking inspiration from the Birmingham rapper, Lady Leshurr, as well as Bugzy Malone from Manchester, and saw a kind of equivalence between these artists and himself: 'I respect them because they are doing their thing for their city. They're doing what I- what we're all trying to do really'. Rap 
culture is thriving in a range of urban centres in England - including Bristol, Birmingham, Nottingham and Manchester to name but a few. However, London is clearly an important junction point. London's prominence is evident both in terms of the sheer scale of cultural and economic activity surrounding rap in the capital as well as the symbolic power of London rap culture.

The grime scene is strongly associated with London, in general, and Bow in east London in particular (Bramwell 2015). However, other parts of capital, such as Brixton (which is associated particularly with UK drill and the 'road rap' genre that preceded it), also continue to play a significant role in structuring understandings of 'UK' rap culture. What is striking is that despite the rhetoric of 'UK' or 'British' rap by Stripzz and others, locations in Scotland, Wales and Northern Ireland are rarely (if ever) mentioned by rappers from cities in England. Even in Bristol, we have not once encountered Welsh people or places being referenced in relation to rap culture, despite the Welsh border being less than 20 miles away and Cardiff, the Welsh capital city, just over 40 miles away. By contrast, references to rappers and rap scenes in English cities like nearby Gloucester as well as Birmingham, Nottingham and Manchester are relatively common. We argue that through the performance of rap lyrics in cities across England, and the circulation of rappers' representations of themselves, their neighbourhoods, and their cities in music videos, a distinctive 'UK' rap culture is imagined, performed, and practiced in young people's everyday lives, through a network of translocal cultural flow that privileges urban centres in England. Although grime culture is present in Cardiff and Glasgow, the rap scenes in these cities are obscured by the prominence of these translocal English networks that make up 'UK' rap culture.

\section{Negotiating Territory, Performing Translocality}

One Wednesday evening in spring 2016, we arrived at the studio in Docklands, Bristol, and walked in on a noticeably tense atmosphere and a serious conversation taking place 
between a few young people and Duppy, Hans and Cherelle, the team of adults that run the studio. It transpired that Stripzz's crew had become the subject of 'beef' from another crew circulated online through a music video. The offending crew had shot a video in the neighbourhood of a rival group, and in the course of their track rapped the line 'them man don't want smoke, they're like Oosowavey'. For the Oosowavey boys, this had been an unprovoked attack, drawing them into a kind of territorial conflict that they did not want to be involved with. Noticeably affected by the situation, Stripzz, was keen to push back and saw the recording booth as a place to do it. However, this was not to be a titfor-tat exchange but an attempt to take the higher ground by focusing on his 'own thing'. He had arranged to record a collaboration that night with Murkzy, another young rapper he had been communicating with on Facebook Messenger. Murkzy delivered his contribution to the track first, and he was immediately followed into the booth by Stripzz, with staff-member Cherelle recording the track and acting as their producer. Reading from a sheet of A4 paper, Stripzz delivered his lines into the mic, gesturing with his right hand as he rapped. Stripzz's verse refered to both Bristol and the South West, but his declaration that he is 'reppin' Bris' not Endz' [representing the whole city, not just his neighbourhood] conveys a desire to project himself beyond the territorial disputes of local groups. The song ends with the lines 'Beef I just lef' it. I'm here for the grind no question./ My young G's show progression. Hater's that I'm your obsession.' When he emerged from the booth, Stripzz was both energised and very pleased with his performance. We asked what the track was called and, after briefly conferring, they agreed 'Shook'.

Less than three weeks later a full music video for 'Shook' had been shot and posted on SimzCityTV, the same YouTube channel as the video that had prompted Stripzz's response. In that video the crew that insult Oosowavey - drawing on the conventions of the drill 
genre - walk down a high-street, point to the sign of a local pub, and clearly identify their ability to occupy local territory. By contrast, the music video for 'Shook' depicts Stripzz and Murkzy standing in and walking through Bristol's streets and a local housing estate.

'Shook' is shot during the daytime and, although various vehicles enter the frame, there are no images of street signs. While the video is clearly set in a residential area, there is no attempt to identify this particular locale within the city. This music video is tightly focused on the performance of the two rappers, and the chorus emphasises their social orientation:

Mum told me not every single person you meet is good

Don't matter where they come from, from the rich parts or from the 'hood

So I'm gonna stay in my lane, man can't take me for a mook

Don't care who you are, don't care where you're from

Go and let another man go and think I'm shook.'

The representation of a resilient masculinity in this music video is constructed through a particular orientation to locality: 'reppin' Bris' not Ends'. The song's emphasis on resisting 'beef', its disavowal of territorial allegiance, the affirmation of a maternal moral figure, and the MCs' prioritisation of personal development, contributes to a struggle over the shape and meaning of contemporary urban dwelling and citizenship. Rather than seeing representations of the 'neighbourhood' solely as part of a generic formula, 'Shook' is better understood as a response to another video. Therefore this representation is part of a cultural debate about the scale on which black urban life should be lived, and the role of one's locality in shaping identity.

Importantly, for Stripzz, his representation of himself on Bristol's streets is not solely a representation of his city but also a representation of the nation:

It's like Stormzy, he's obviously back in London because he's from London, but then he's repping the whole of the UK, because he's from the UK, right? So I'm repping Bristol, but then obviously Bristol is the UK, so I'm repping UK as well. But there's no UK or Bristol, it's just both equally.

This imagined connection between specific cities, through which representations of the 'whole of the UK' are produced, highlights the importance of a particular form of translocality in English rap culture. The performance of rap songs and the circulation of 
videos by artists and crews such as Billy, Stripzz and Murkzy contributes to an alternate public sphere through grassroots rap culture. In After Empire, Paul Gilroy (2004) highlights how songs, by figures such as Mike Skinner, have a 'precious ability to transport English ethnicity into the present.' We want to build on this observation and suggest that the communicative technologies that connect London's black public sphere (Baker 1996; Bramwell 2015) to those of other urban centres, have facilitated a reimagining of national identity that is meaningful to ordinary young people.

\section{Reimagining Englishness}

We argue that rap is a medium through which alternative English identities are performed. In our research on rap culture in England we have encountered a wide range of national and ethnic subject positions, ranging from deep affirmations of Englishness through to bold negations of (hegemonic) English identity. These various subject positions are constructed through an engagement with a network of black cultural production and consumption that links various urban centres in England and from which emerges a rap culture that is widely conceived and experienced as distinctly 'UK'. Notably, 'UK' in this context often operates as an unconscious euphemism for England. We argue that a generation of youths actively construct identities and feel intimately connected to an English rap culture, even while many of those youths might disavow or be ambivalent towards Englishness writ large.

Talk about English identity and governance has gained increasing prominence in public consciousness and political discourse in recent years. This is due, in large part, to devolution processes that have transferred legislative power from the United Kingdom Parliament to the newly-founded Scottish Parliament (1999) and National Assembly for Wales (1998). Meanwhile, England has continued to be wholly governed by the UK Parliament. This situation has fortified Scottish and, to a lesser extent, Welsh, nationalism, leaving English identity and politics in a state of confusion and uncertainty. That 
uncertainty has been intensified through debates during and after the referendum on Scottish independence in 2014 and the European Union membership referendum in 2016. Since the mid-twentieth century, English nationalism developed as a relatively niche political project of the Right. Figures such as John Major (1993) and Roger Scruton (2016) have attempted to construct notions of England and Englishness, typically by drawing on mythical images of a tranquil rural or suburban past. These attempts to stabilise a spectral Englishness, fortify their fragile but hegemonic images by conjuring notions of a deep historical continuity (Anderson 1991) of an ethnically homogeneous national community.

Recently, figures on the Left, such as the former Labour Government Minister, John Denham, and the Labour MP, Tristram Hunt, have made the case for the Left to embrace and help shape a distinctly English identity and politics. In 2016, prior to the European Union membership referendum, Hunt argued that 'the Labour Party has not been explicit enough about its love of the country' in a 'contemporary Europe where the politics of national identity demand whole new levels of confidence when it comes to defending the national interest.' While we agree that English identity must be the subject of renewed political debate, we find it necessary to highlight that even in Hunt's appeal to embrace English identity his references to 'the wild England of peaks and lakes; the historic England of country houses, minsters and castles' conjure notions of an England inhabited by relatively few today. It is important to highlight that the opening up of Britishness to blacks and Asians was the result of sustained cultural, political and scholarly work (Hall 1995). We suggest that for politicians to play a role in shaping the forms and values that define England, in a manner that is relevant to the experiences of those that they seek to represent, greater engagement with how English identity is constructed through the nation's popular cultures is required. Furthermore, we argue that as one of the most popular musical genres in the UK, rap music provides an important portal through which to examine how young people in England represent themselves and develop a sense of 
national belonging that is distinct from that promoted by either the political Right or Left. This cultural and political work is made all the more necessary in the context of Brexit, where the aims of the UK government often operate in sharp divergence to the varied interests and ambitions of the United Kingdom's constituent nations.

Chilli, whose mother is from Newcastle and father from Pakistan, grew up in east London and feels a strong sense of Englishness:

I feel English as fuck ... I definitely feel English, like now obviously I know my roots now, and like I'm half Pakistani, half English. But I was brought up English and my dad wasn't about, so I was brought up with my mum around Upton Park, like proper East London Cockney kind of shit. Like caf' in the morning, and all of that malarkey. Chilli's representation of Englishness is constructed not only through reference to his mother's national identity, but also to particular forms of language and sociality. Chilli first came to participate in hip hop and grime cultures through school and is now a full-time dancer, specialising in breakdance. Despite growing up within the context of the emerging grime scene, he exercised a choice over the kind of rap culture in which he participated.

When I was in secondary school grime played a big part in it, and everyone was spitting bars, so everyone was spraying. I wasn't really - I was into it, but I never did it myself. But it was only until after I got into hip hop, and it wasn't so much the grime that influenced me, it was more so the hip hop. ... Now, if I spit, I will spit grime more so to hip hop.

Alongside his informal learning and participation in rap culture in the playground, Chilli's school also provided him with his first opportunity to engage with breakdance. 'I started as like just doing dance at my school, and I was learning breakdancing on the side. And then as I was kind of getting into it and I was starting to learn more, I just ended up taking the B-boy route.' Although his early interests in rap culture were developed through hip hop, in preference to grime, Chilli's current inclination towards grime draws on notions of the authenticity and social relevance of rap from the UK, in comparison to US hip hop.

I think I just listen to better UK music, but it's just like you can relate to it. With American music it's all cool, whereas it's just like super swaggy or just super like gangbangy. But with UK it's like just makes more sense to me, innit, really? It's like it's not so gang-bangy, but the slang is the same, the situation is the same. 
These contrasting orientations, towards both the US and the UK, highlight the issues present in attempting to think critically about black cultural traditions and the role that rap plays in identity formation. Here, the question of origins is put into abeyance, while rap's relevance to social circumstances and lived experience is brought to the fore.

Furthermore, Billy and Chilli's participation in rap performances reveal how the interests and identifications that are shared by the denizens of these urban spaces are explored through this cultural form (denizens who of course boast a complex array of racial and ethnic backgrounds). This coincides with Monique Charles' notion of the 'grime generation', held together by what she describes as 'cross-race working-class identities' (Charles 2018). While Charles' frame of reference centres on London we want to highlight how such identities operate beyond the capital, translocally, in and between ethnically diverse working-class urban centres in England and, in turn, provoking a reimagination of an English public, from the ground up.

This public, which is given shape by the performance and circulation of rap culture, points to an emergent sense of national belonging that is largely unrecognised by the political mainstream. However, the engagement with grime artists by the Labour Party leader Jeremy Corbyn in the run up to the 2017 UK General Election and the corresponding rallying of the 'Grime4Corbyn' movement presents us with an exception. Jones (2018) argues that under the leadership of Jeremy Corbyn the Labour Party was more willing to engage with youth issues, which 'played an important part in the upswing in turnout and political engagement by young people in 2017.' In turn, a number of 'organic intellectuals' within the grime scene came out in support of Corbyn (Charles 2018). We suggest that the coincidence of Corbynite politics and grime has to do, in large part, with Corbyn's upturning of the status quo, leading to a reimagination of national belonging via the prism of social justice in a way that privileges urban, ethnically-diverse and working class subjectivies. While we have observed a strong orientation towards 
collaborative practices and concern with urban life in rap culture, what also emerges from our translocal ethnography is a significant emphasis on forms of belonging, social justice, and collective self-improvement. We argue that a more sustained engagement with the experiences and practices of these urban youths is required by political leaders. Through such sustained engagement it may be possible to foster the nascent sense of national identity that we have observed, which is grounded in lived (trans)local experience and therefore meaningful and relevant to contemporary England's multi-ethnic citizenry.

\section{Conclusion}

In this article we have attempted to move beyond the transnational framework that underpins global hip hop studies. Through the development of a translocal ethnography, we have examined how young people perform place based identities through rap. By focusing on grassroots rap culture we have been able to identify how young people construct translocal subjectivities through the production, dissemination and use of rap lyrics and music video. Although this translocal ethnography is unable to develop the deep engagement with a single, geographically bounded, community, possible through traditional ethnographic practice, it opens possibilities for understanding processes through which young people's highly translocal and highly local subjectivities are constructed. Place based identities are not only produced through rhetorical invocations of place, but also through the practical activity of gesture, bodily signification and the conjuring of ethnic and cultural associations in rap performances. Within this grassroots rap culture, translocal identifications are performed through the use and reuse of rap lyrics and music videos produced in other towns and cities, as well as through young people's construction of imaginary relations with rappers from those places.

\section{Funding}

This work was supported by the Arts and Humanities Research Council [AH/Mo11275] 


\section{References}

Anderson, B. 1991. Imagined Communities: Reflections on the Origin and Spread of Nationalism. London: Verso.

Appadurai, A. 1996. Modernity at Large: Cultural Dimensions of Globalization. University of Minnesota Press.

Back, L. 1988. 'Coughing Up Fire: Soundsystems in South-East London’ New Formations.

Baker, H. 1996. "Critical Memory and the Black Public Sphere" The Black Public Sphere. Chicago: University of Chicago Press.

Bennett, A. 1999a. "Rappin' on the Tyne: White Hip Hop Culture in Northeast England” The Sociological Review 47:1.

Bennett, A. 1999b. 'Hip hop am Main: the localization of rap music and hip hop culture' Media, Culture and Society 21:1.

Bradley, L. 2013. Sounds Like London: 100 Years of Black Music in the Capital. London: Serpent's Tail.

Bramwell, R. .2015. UK Hip Hop, Grime and the City: The Aesthetics and Ethics of London's Rap Scenes. London: Routledge.

Brickell, K. and Datta, A., eds. 2011. 'Introduction: Translocal Geographies' Translocal Geographies: Spaces, Places, Connections. Farnham: Ashgate.

Chang, J. 2005. Can't Stop, Won't Stop: A History of the Hip-Hop Generation. London: Ebury Press.

Charles, M. 2018. 'Grime Labour' Soundings. 68.

Condry, I. 2006. Hip-Hop Japan: Rap and the Paths of Cultural Globalization. Durham and London: Duke University Press.

Darling-Wolf, F. 2008. 'Getting Over Our "Illusion d'Optique”: From Globalization to Mondialisation (Through French Rap)' Communication Theory. 18.

Dedman, T. 2011. 'Agency in UK hip-hop and grime youth subcultures: peripherals and purists' Journal of Youth Studies. Vol 14 No. 5: 507-522

Elafros, A. 2013. 'Greek hip hop: Local and translocal authentication in the restricted field of production' Poetics. 41.

Englert, B. 2018. 'Looking through two lenses: reflections on transnational and translocal dimensions in Marseille-based popular music relating to the Comoros' Identities. 25:5.

Gilroy, P. 1987. There Ain't No Black in the Union Jack: The Cultural Politics of Race and Nation. London: Unwin Hyman.

Gilroy, P. 1991. 'Sounds Authentic: Black Music, Ethnicity and the Challenge of a "Changing” Same’ Black Music Research Journal. 11:2.

Gilroy, P. 2004. After Empire: Melancholia or Convivial Culture?: Multiculture or Postcolonial Melancholia. Oxon: Routledge. 
Greiner, C. and Sakdapolrak, P. 2013. 'Translocality: Concepts, applications and emerging research perspectives' Geography Compass. 7:5

Habermas, J. 1989. The Structural Transformation of the Public Sphere. Cambridge: Polity.

Hall, S. 1995. 'New Ethnicities' in The Post-Colonial Studies Reader. Bill Ashcroft, Gareth Griffiths and Helen Tiffin, eds. London: Routledge 223-227.

Hancox, D. 2018. Inner City Pressure. London: William Collins.

Heathcott, J. 2003. "Urban Spaces and Working-Class Expressions across the Black Atlantic: Tracing the Routes of Ska” Radical History Review. 87: 183-206

Hesmondhalgh, D. and M. Casper. 2001. 'Urban Breakbeat Culture', Global Noise, edited by Tony Mitchell, 86-110. Middletown, Connecticut, Weslyan University Press.

Hoyler, M. and Mager, C. 2005. 'HipHop ist im Haus: Cultural Policy, Community Centres, and the Making of Hip-Hop Music in Germany'. Built Environment. 31/3.

Hunt, T. 2016. 'Labour must embrace Englishness - and be proud of it' The Guardian. https://www.theguardian.com/commentisfree/2016/feb/o5/labour-embrace-englishnessproud-patriotism.

Johnson, L. K. 1976. “Jamaican Rebel Music” Race \& Class. 17: 397-412.

Jones, R. 2018. 'Music, politics and identity: from Cool Britannia to Grime4Corbyn' Soundings. 67.

Kajikawa, L. 2015. Sounding Race in Rap Songs. Oakland: University of California Press.

Kim, H. 2012. “A 'desi' diaspora? The production of 'desiness' and London's Asian urban music scene” Identities: Global Studies in Culture and Power. 19 (5): 557-575

Ma, E. 2002. 'Translocal spatiality' International Journal of Cultural Studies. 5.

Major, J. 1993. 'Speech to Conservative Group for Europe'.

http://www.johnmajor.co.uk/page1086.html.

McRobbie, A. and Garber, J. 1993. 'Girls and Subcultures' in Resistance through Rituals, edited by Hall and Jefferson, 177-188, Oxford and New York: Routledge.

Mitchell, T. ed. 2001. Global Noise: Rap and Hip-Hop Outside the USA. Middletown, Connecticut: Weslyan University Press.

Perkins, W. 1996. Droppin Science: Critical Essays on Rap Music and Hip Hop Culture. Philadelphia: Temple University Press.

Thapar, C. 2017. 'From Chicago to Brixton: The surprising rise of UK drill'. https://www.factmag.com/2017/04/27/uk-drill-chicago-brixton/

Turner, P. 2017. Hip Hop Versus Rap: The Politics of Droppin' Knowledge. London and New York: Routledge. 
Nitzsche, S. and Grunzweig, W. eds. 2013. Hip-Hop in Europe: Cultural Identities and Transnational Flows.

Noys, B. 1995. 'Into the Jungle' Popular Music 14 (3): 321-332

Scruton, R. 2016 ‘Who are we?’ Prospect Magazine

Smith, M. 2011. 'Translocality: A Critical Reflection' Translocal Geographies: Spaces, Places, Connections, edited by Brickell, K. and Datta, A., 181-198. Farnham: Ashgate.

White, J. 2016. Urban Music and Entrepreneurship: Beats, Rhymes and Young People's Enterprise. London and New York: Routledge.

White, J. 2017. 'Controlling the Flow: How Urban Music Videos Allow Creative Scope and Permit Social Restriction' Young 25 (4). 